\title{
New Books on the History of Medicine
}

John C Burnham (1998)

How the Idea of Profession Changed the Writing of Medical History

Medical History Supplement No. 18, pp. 206

Illus. ISBN 085484067 2, £32, US\$50 (doth)

Christopher Lawrence, Paul Lucier, and Christopher Booth (eds) (1997)

"Take time by the forelock": The letters of Anthony Fothergill to James Woodforde, 1789-1813

Medical History Supplement No. 17, pp. 143 ISBN $0854840664, £ 32$, US\$50 (cloth)

\section{Elizabeth M R Lomax (1996)}

Small and Special:The development of hospitals for children in Victorian Britain Medical History Supplement No. 16, pp. 224 Illus., ISBN $0854840648, € 25$, US\$38 (cloth)

\section{E M Tansey, P P Catterall, D A}

Christie, SVWillhoft, L A Reynolds (eds) (1997)

Wellcome Witnesses to Twentieth Century Medicine, volume 1, Witness Seminar Transcripts

Occasional Publication No. 4, pp.140 ISBN 186983579 4, £9, US\$17 (paperback)

Please send orders, by either mail, fax, telephone, e-mail or web, to:

Tracy Tillotson

Wellcome Institute for the History

of Medicine

183 Euston Road

London NW1 2BE, UK

The Wellcome Trust is a registered charity, no. 210183
E M Tansey, D A Christie, LA Reynolds (eds) (1998)

Wellcome Witnesses to Twentieth

Century Medicine, volume 2, Witness

Seminar Transcripts

Occasional Publication No. 6. pp. 288

ISBN $1869835395, £ 12.50$, US\$21 (paperback)

Compiled by Jaap Harskamp (1997)

Dissertatio medica inauguralis...Leyden medical dissertations in the British Library 1593-1746. Catalogue of a Sloane-inspired collection.

pp. 270

$£ 9$, US\$17 (paperback)

W F Bynum (ed.) (1997)

Gastroenterology in Britain: Historical essays Occasional Publication No. 3, pp. 138

ISBN 186983564 6, Ł8.00, US\$13 (paperback)

Jonathan Andrews (1998)

'They're in the Trade... of Lunacy/They 'cannot interfere'...they say": The Scottish Lunacy Commissioners and Lunacy Reform in Nineteenth-century Scotland

Occasional Publication No. 8, pp. 108

ISBN 085484068 0, Ł8, US\$13 (paperback).

Tel: $+44(0) 1716118486$

Fax: +44 (0)171 6118703

E-mail: t.tillotson@wellcome.ac.uk

Web: wnw.wellcome.ac.uk

Payment in US\$ by credit card only, add $\$ 5$ for postage and packing. To pay in pounds sterling please send a cheque for the amount, plus $\notin 3$ p\&p drawn on a UK bank account, or send credit card details.

\section{(6) The Nelleome Irus}


Rare Books \& Manuscripts in the history of

Medicine \& the Sciences BOUGHT·SOLD·APPRAISED

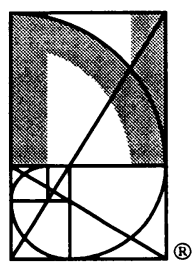

Send for our latest catalogue Jeremy Norman \& Co., Inc.

Norman Publishing

720 Market Street

San Francisco, California 94102

(415) 781-6402

FAX (415) 781-5507

www.historyofmedicine.com

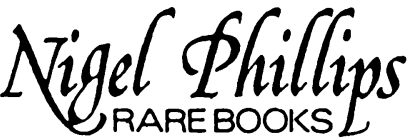

Antiquarian books in the history of medicine and the health sciences.

Please send for my catalogue, or telephone for an appointment when in London.

5 BURLEIGH PLACE PUTNEY

LONDON SW15 6ES ENGLAND

Tel: 01817882664

Fax: 01817801989

\section{Antiquarian Books}

\section{concerning}

\section{Medicine, the Sciences}

\section{\& Natural History}

Catalogues issued - Commissions \& Valuations undertaken Visitors welcome by Appointment

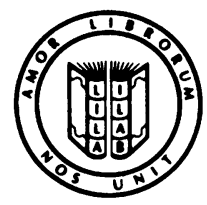

\section{MICHAEL PHELPS}

Allfreys House $\cdot$ Bolney Road

Cowfold · West Sussex RH13 8AZ

Telephone: +44 (0) 1403864049

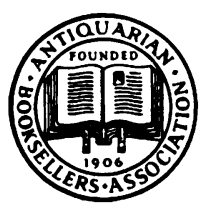

Fax: +44 (0) 1403864730 